\title{
Heightened Amygdala Long-Term Potentiation in Neurotensin Receptor Type-I Knockout Mice
}

\author{
Taiju Amano',2,3, Etsuko Wada',3, Daisuke Yamada',3, Ko Zushida', ${ }^{1,3}$, Hiroshi Maeno',4, Mami Noda ${ }^{2}$, \\ Keiji Wada $^{1,3}$ and Masayuki Sekiguchi*,,3 \\ 'Department of Degenerative Neurological Diseases, National Institute of Neuroscience, National Center of Neurology and Psychiatry, Tokyo, \\ Japan; ' 2 Laboratory of Pathophysiology, Graduate School of Pharmaceutical Sciences, Kyushu University, Fukuoka, Japan; ${ }^{3}$ CREST, Japan Science \\ and Technology Agency, Saitama, Japan
}

\begin{abstract}
Neurotensin receptor type-I (Ntsrl) is the main receptor subtype that underlies neurotensin (NT)-mediated modulation of the dopamine (DA) system. Although NT and DA coexist in the basolateral nucleus of the amygdala (BLA), the function of Ntsrl in the amygdala is not well characterized. In the present study, we utilized Ntsrl knockout (Ntsrl-KO) mice to examine the role of Ntsr I in the amygdala. In acute brain slices of Ntsr I-KO mice, synaptic currents elicited in BLA pyramidal neurons by electrical stimulation of the lateral nucleus of the amygdala (LA) were greatly potentiated by tetanic stimulation (BLA-long-term potentiation (LTP)). Such potentiation was not evident in pyramidal neurons of wild-type mice. In the presence of an antagonist of Ntsr I, SR48692, BLA-LTP was consistently observed in the neurons of wild-type mice, suggesting that both inherited deletion and acute pharmacological blockade of Ntsrl induce BLA-LTP. BLA-LTP in Ntsr I-KO mice was impaired by sulpiride, a DA D2-like receptor antagonist. Conversely, quinpirole, a $D_{2}$-like receptor agonist, induced pronounced BLA-LTP in wild-type mice, suggesting the upregulation of $D_{2}$-like receptor activity in $\mathrm{Ntsr}$ - KO mice. The ratio of NMDA receptor-mediated to non-NMDA receptor-mediated synaptic currents in Ntsrl-KO mouse BLA neurons was approximately double that measured in wild-type mouse neurons. Furthermore, quinpirole potentiated NMDA receptormediated synaptic currents in the BLA of wild-type mice. These results suggest that, without Ntsrl, synaptic responses from the LA to BLA pyramidal neurons undergo LTP in response to tetanus stimulation through facilitation of $D_{2}$-like receptor-induced activation of NMDA receptors.

Neuropsychopharmacology (2008) 33, 3135-3145; do::I0.1038/npp.2008.38; published online 19 March 2008
\end{abstract}

Keywords: neurotensin receptor type- I; dopamine; basolateral amygdala; LTP; knockout

\section{INTRODUCTION}

Neurotensin (NT) is a 13-amino-acid peptide that is present in many brain regions. It is well established that NT receptor activation produces a variety of effects on dopamine (DA) signaling (Binder et al, 2001b). For example, enhanced NT neurotransmission prevents the effect of psychostimulants on prepulse inhibition (PPI) of the acoustic startle (Caceda et al, 2005; Feifel et al, 1999). Conversely, NT receptor antagonist blocks the effect of antipsychotics on PPI (Binder $e$ t al, 2001a). Three subtypes of NT receptors, NT receptor type-1, type-2, and type-3

*Correspondence: Dr M Sekiguchi, Department of Degenerative Neurological Diseases, National Institute of Neuroscience, National Center of Neurology and Psychiatry, 4-I-I Ogawahigashi, Kodaira, Tokyo 187-8502, Japan, Tel: +8I 42346 17|5, Fax: + 8I 42346 1745, E-mails: elecl@ncnp.go.jp or sekiguch@ncnp.go.jp

${ }^{4}$ Current address: Department of Neuroscience, School of Medicine, Case Western Reserve University, 10900 Euclid Avenue, Cleveland, $\mathrm{OH} 44106$, USA

Received 20 July 2007; revised 25 January 2008; accepted I 5 February 2008
(Ntsr1, Ntsr2, and Ntsr3), are known thus far. Both Ntsr1 and Ntsr2 are G-protein-coupled cell surface receptors (Chalon et al, 1996; Tanaka et al, 1990), whereas Ntsr3 is a single-transmembrane domain protein that mainly localizes intracellularly (Mazella et al, 1998; Sarret et al, 2003). Among these three receptors, Ntsr1 is the main receptor subtype that mediates NT-DA interactions (Binder et al, 2001a; Caceda et al, 2005). The mode of Ntsr1-DA receptor interaction varies with cells and brain regions. For example, in striatal neurons, NT suppresses presynaptic $\mathrm{D}_{2}$-like autoreceptors, which results in an increased level of extracellular DA (Diaz-Cabiale et al, 2002; Ferraro et al, 1997). Notably, Ntsr1 decreases the agonist-binding affinity of $\mathrm{D}_{2}$-like receptors via allosteric Ntsr1-D $\mathrm{D}_{2}$-like receptor interactions (Diaz-Cabiale et al, 2002; von Euler et al, 1989). In the prefrontal cortex, NT activates GABAergic interneurons via Ntsr1, probably downstream of $\mathrm{D}_{2}$-like autoreceptor (Petrie et al, 2005).

The amygdala, which receives NT and DA projections, performs a central role in the evaluation of aversive stimuli and associative learning underlying conditioned fear memory (Davis, 1997; Fendt and Fanselow, 1999; LeDoux, 
2000; Maren, 1999). Fear responses are blocked by the inhibition of the amygdaloid DA receptor (Greba et al, 2001; Greba and Kokkinidis, 2000; Guarraci et al, 1999, 2000). In the lateral nucleus of the amygdala (LA), DA gates longterm potentiation (LTP) of synaptic inputs to the LA pyramidal neurons through the blockade of GABAergic interneurons (Bissiere et al, 2003). In the intercalated cell masses, DA hyperpolarizes GABAergic neurons (Marowsky et al, 2005). Moreover, it has been reported that DA modulates cell excitability and input resistance of pyramidal neurons in the basolateral nucleus of the amygdala (BLA) (Kroner et al, 2005). Some of the DA fibers projecting to the BLA neurons are DA-NT mixed fibers (Asan, 1998). Furthermore, the BLA contains NT-binding sites (Moyse et al, 1987) and Ntsr1-positive cells (Alexander and Leeman, 1998). However, the effects of NT on the DA system in the BLA have not been reported.

In the present study, we utilized Ntsr1 knockout (Ntsr1-KO) mice (Maeno et al, 2004) to examine the role of Ntsr1 in the BLA. Because BLA receives projections from LA neurons (Pitkanen et al, 1995, 1997), we investigated the electrophysiological properties of projections from LA neurons to the BLA neurons in wild-type and Ntsr1-KO mice. A pronounced LA tetanic stimulation-induced LTP in BLA pyramidal neurons (BLA-LTP) was observed in brain slices from Ntsr1-KO mice but not in slices from wild-type mice. The absence of Ntsr1 augments a DA $D_{2}$-like signal that induces BLA-LTP in the KO mice. Moreover, we found that synaptic currents mediated by NMDA receptors were increased in the BLA pyramidal neurons of Ntsr1-KO slices compared with wild-type. These results suggest that, without Ntsr1, synaptic responses from the LA to BLA pyramidal neurons undergo LTP in response to tetanus stimulation through facilitation of $\mathrm{D}_{2}$-like receptor-induced activation of NMDA receptors.

\section{MATERIALS AND METHODS}

\section{Materials}

Quinpirole, SCH23390, SKF81297, picrotoxin, D-APV, MK801, and CNQX disodium salt were purchased from Sigma (St Louis, MO). Halothane was from Takeda (Osaka, Japan), CGP46381 was from Tocris Bioscience (Bristol, UK), and ( \pm )-sulpiride was from RBI (Natick, MA). Other reagents were of analytical purity and were obtained from Sigma or Wako (Osaka, Japan). SR48692 was kindly supplied by Sanofi-Synthelabo Research (Malvern, PA). All reagents except for sulpiride and SCH23390 were dissolved in distilled water at high concentrations and diluted to the working concentration with artificial cerebral spinal fluid (ACSF, see below). Sulpiride was dissolved in $0.1 \mathrm{~N} \mathrm{HCl}$, neutralized to $\mathrm{pH} 7.3$ by the addition of $0.1 \mathrm{~N} \mathrm{NaHCO}_{3}$, and diluted with ACSF. SCH23390 was dissolved in dimethylsulfoxide and then diluted with ACSF.

\section{Animals}

Ntsr1-KO mice were generated as described (Maeno et al, 2004) and backcrossed 25-31 times with C57BL/6J mice. Animals for the experiments were generated by the mating of heterozygous mice. All animals were housed in a temperature-controlled room $\left(22^{\circ} \mathrm{C}\right)$ with a 12 -h light-dark cycle (lights on at 0800 hours). Food and water were available ad libitum. Animal procedures were in strict accordance with the guidelines of the National Institutes of Neuroscience, National Center of Neurology and Psychiatry (Japan) and were approved by the Institutional Animal Investigation Committee.

\section{Electrophysiology}

Electrophysiological recording from BLA pyramidal neurons was carried out as reported (Zushida et al, 2007). Briefly, we used 300- $\mu$ m-thick coronal brain slices from 4- to 5-week-old male wild-type or Ntsr1-KO mice. The animals were anesthetized with halothane, and the brain was quickly removed and sliced with a Vibratome 3000 (Vibratome, St Louis, MO) in ACSF (124 mM NaCl, $3 \mathrm{mM}$ $\mathrm{KCl}, 2 \mathrm{mM} \mathrm{CaCl}_{2}, 1.2 \mathrm{mM} \mathrm{KH_{2 }} \mathrm{PO}_{4}, 1.3 \mathrm{mM} \mathrm{MgSO} 4,26 \mathrm{mM}$ $\mathrm{NaHCO}_{3}, 10 \mathrm{mM}$ glucose, $\mathrm{pH} 7.35,295$ mosM) equilibrated with $95 \% \mathrm{O}_{2} / 5 \% \mathrm{CO}_{2}$ at $2.5^{\circ} \mathrm{C}$. Before transfer to a recording chamber (the volume was approximately $1.5 \mathrm{ml}$ ), slices were maintained for at least $60 \mathrm{~min}$ at room temperature in ACSF. A brain slice was perfused $(3.0 \mathrm{ml} / \mathrm{min}$, gravity flow) with ACSF adjusted to $28-32^{\circ} \mathrm{C}$ by an in-line heater and an automatic temperature controller (Warner Instruments, Hamden, CT). Patch electrodes (resistance 5-8 M $\Omega$ ) were made from borosilicate capillary tubes (WPI, Sarasota, FL) and filled with a solution containing $105 \mathrm{mM} \mathrm{K}$-gluconate, $30 \mathrm{mM} \mathrm{KCl}, 10 \mathrm{mM}$ HEPES, $0.5 \mathrm{mM}$ EGTA, $1 \mathrm{mM} \mathrm{MgCl}_{2}$, $12 \mathrm{mM}$ Na-phosphocreatine, $4 \mathrm{mM}$ Mg-ATP, $0.5 \mathrm{mM}$ Na-GTP, pH 7.3, 295 mosM (internal solution A) in most studies. In some examinations in which inhibitory postsynaptic current (IPSC) was recorded, patch electrodes were filled with a low- $\mathrm{Cl}^{-}$solution containing $132 \mathrm{mM}$ K-gluconate, $3 \mathrm{mM} \mathrm{KCl}, 10 \mathrm{mM}$ HEPES, $0.5 \mathrm{mM}$ EGTA, $1 \mathrm{mM} \mathrm{MgCl} 2,12 \mathrm{mM}$ Na-phosphocreatine, $1 \mathrm{mM} \mathrm{Mg-ATP}$, $0.5 \mathrm{mM}$ Na-GTP, pH 7.3, 295 mosM (internal solution B). For the recording of the NMDA/non-NMDA receptor ratio, we used a solution containing $105 \mathrm{mM} \mathrm{CsOH}, 30 \mathrm{mM} \mathrm{CsCl}$, $10 \mathrm{mM}$ HEPES, $0.5 \mathrm{mM}$ EGTA, $1 \mathrm{mM} \mathrm{MgCl}_{2}, 12 \mathrm{mM}$ Na-phosphocreatine, $4 \mathrm{mM}$ Mg-ATP, $0.5 \mathrm{mM}$ Na-GTP, pH 7.3 adjusted with gluconic acid, 295 mosM (internal solution C). Pyramidal-shaped large BLA cells were visually identified using an infrared differential contrast video system with an upright microscope (BX50WI; Olympus Optical Co., Ltd., Tokyo, Japan). Whole-cell patch clamp recordings were performed from the soma of these cells in voltageclamp mode unless otherwise noted. The electrophysiological signal was amplified and filtered at $5 \mathrm{kHz}$ using a WPC-100 patch-clamp amplifier (ESF Electronic, Göttingen, Germany) or MultiClamp 700B patch-clamp amplifier (Axon Instruments, Union City, CA). Data were digitized at $50 \mathrm{kHz}$ and acquired with Pulse/Pulsefit software (ver. 8.5.3; HEKA, Lambrecht/Pfalz, Germany) or Clampex (ver. 9.2; Axon Instruments). Input resistance was monitored every $30 \mathrm{~s}$, and if the value varied by $>20 \%$ the data were discarded. We did not check access resistance values continuously, although we checked it at the beginning and end of some, although not all, of the recordings by reading the value indicated in our amplifier operating software. The initial values of access resistance ranged from 15 to $35 \mathrm{Mohm}$, and the value did not substantially change in 
successful recordings. The LA was stimulated with a bipolar stainless steel stimulation electrode (David Kopf Instruments, Tujunga, CA, see Figure 1a). During the tetanus, recording was performed in current-clamp mode. The pulse intensity was adjusted to produce approximately $30 \%$ of the maximum amplitude in all experiments. The average amplitude of the 20 synaptic responses just prior to tetanic stimulation was taken as the baseline, and post-tetanus values were normalized to this averaged value. The stimulus frequency during the baseline period was $0.033 \mathrm{~Hz}$. Each drug was dissolved in ACSF and bath was applied by switching the perfusion solution.

\section{Statistical Analysis}

The two-tailed Student's $t$-test was used for statistical comparisons between two groups. One-way analysis of variance followed by Fisher's PLSD test was used for multiple comparisons.

\section{RESULTS}

\section{BLA-LTP is Enhanced in Ntsr1-KO Mice}

A total of 101 BLA neurons in wild-type mice and 100 neurons in Ntsr1-KO mice were studied. The resting membrane potential, action potential threshold, and input resistance did not differ significantly between wild-type and Ntsr1-KO mice (Figure $1 \mathrm{~b}$ and $\mathrm{c}$ ). At a holding potential of $-70 \mathrm{mV}$, stimulation of LA evoked inward currents in BLA pyramidal neurons that were completely blocked by application of CNQX $(20 \mu \mathrm{M})$, an AMPA receptor antagonist (Figure 1d). Under our recording conditions, the reversal potential of pharmacologically isolated $\mathrm{GABA}_{\mathrm{A}}$ receptormediated synaptic currents in the presence of CNQX $(20 \mu \mathrm{M}), \mathrm{MK}-801$ (antagonist of NMDA receptor, $20 \mu \mathrm{M})$, and CGP46381 (antagonist of $\mathrm{GABA}_{\mathrm{B}}$ receptor, $20 \mu \mathrm{M}$ ) was $-70.1 \pm 1.8 \mathrm{mV}$ in wild-type slices $(n=6)$ and $-72.6 \pm 2.6 \mathrm{mV}$ in Ntsr1-KO slices $(n=8$; Figure $1 \mathrm{e}-\mathrm{g})$ (see Discussion on the differences between the measured and theoretical $\mathrm{Cl}^{-}$equilibrium potentials). Thus, a holding potential of $-70 \mathrm{mV}$ was used in most experiments to minimize the contribution of $\mathrm{GABA}_{\mathrm{A}}$ currents when recording LA-induced synaptic responses. Consistently, $\mathrm{GABA}_{\mathrm{A}}$ receptor antagonist picrotoxin elicited little changes in LA stimulation-evoked synaptic currents in BLA pyramidal neurons at $-70 \mathrm{mV}$, although persistent application elicited epileptiform activity (see Figure 5a).

We induced LTP in BLA pyramidal neurons (BLA-LTP) by applying a tetanic stimulation consisting of $100 \mathrm{~Hz}$ for $1 \mathrm{~s}$ (five times at an interstimulus interval of $10 \mathrm{~s}, 500$ pulses in total) to the LA region (Rammes et al, 2000). Tetanic stimulation was applied in current-clamp mode although baseline and post-tetanus responses were recorded in voltage-clamp mode. Tetanic stimulation did not induce LTP in wild-type slices under our experimental conditions although there was a tendency for the synaptic response to be augmented (Figure 2a; normalized amplitude = $109.1 \pm 10.8 \%, 25-35$ min post-tetanus, $n=9$ ). By contrast, the same tetanus induced pronounced BLA-LTP in Ntsr1KO slices (Figure $2 \mathrm{a} ; 183.5 \pm 12.6 \%, 25-35$ min post-tetanus, $n=8$ ). Figure $2 \mathrm{~b}$ shows the input resistance, normalized to the baseline (pre-tetanus) value, during the LTP recordings shown in Figure 2a. The normalized values did not change substantially throughout the course of the recordings, and the waveform of the current response to step pulse applied for calculating the input resistance (Figure $2 \mathrm{~b}$ inset; the averaged traces of $0-10$ and $25-35 \mathrm{~min}$ for pre- and post-tetanus, respectively) was identical in the pre- and post-tetanus in both wild-type and Ntsr1-KO mice. These data indicated that the cell membrane and patch conditions were stable throughout the course of the LTP recordings. Figure $2 \mathrm{c}$ shows the mean normalized amplitude of the BLA synaptic response $25-35 \mathrm{~min}$ after applying conditioning stimuli that were weaker than the $100 \mathrm{~Hz}$ tetanus stimulation (the data for the tetanus above are included for comparison). In total, 500 pulses at $1 \mathrm{~Hz}$ (for approximately $8.3 \mathrm{~min}$, wild type $n=4$, Ntsr1-KO $n=5$ ) or $10 \mathrm{~Hz}$ (for $5 \mathrm{~s}$, five times at an interstimulus interval of $10 \mathrm{~s}, n=5$, respectively) did not induce plastic changes of the synaptic responses in either wild-type or Ntsr1-KO slice (Figure 2c).

To address whether acute pharmacological blockade of Ntsr1 also induces pronounced BLA-LTP, we utilized SR48692, an Ntsr1 inhibitor (Chalon et al, 1996; Gully et al, 1993; Mazella et al, 1996). In the presence of SR48692 $(10 \mu \mathrm{M})$, the tetanic stimulation induced pronounced LTP in wild-type slices (Figure 3a; $159.0 \pm 17.8 \%, 25-35 \mathrm{~min}$ post-tetanus, $n=7$ ), consistent with results in Ntsr1-KO slices (Figure 2a). However, there was a possibility that the effect of SR48692 on BLA-LTP was nonspecific. Thus, we tested the effect of SR48692 $(10 \mu \mathrm{M})$ on BLA-LTP in Ntsr1KO mice; SR48692 did not further facilitate BLA-LTP (Figure $3 \mathrm{~b} ; 166.7 \pm 22.8 \%, 25-35$ min post-tetanus, $n=4$ ), suggesting that the pharmacological blockade of Ntsr1 induced BLA-LTP.

\section{BLA-LTP in Ntsr1-KO Mice is Abolished by Sulpiride, a $\mathrm{D}_{2}$-Like Receptor Antagonist}

How does Ntsr1 modulate BLA-LTP? DA $\mathrm{D}_{2}$-like receptors are one potential candidate, because there are many reports of NT $\mathrm{D}_{2}$-like receptor interactions (Binder et al, 2001b). To determine the mechanism underlying the effects of Ntsr1 on BLA-LTP, we measured BLA-LTP in the presence of the $\mathrm{D}_{2}$-like receptor antagonist, sulpiride $(20 \mu \mathrm{M})$. As shown in Figure 4a, BLA-LTP in Ntsr1-KO slices was nearly abolished by sulpiride ( $115.7 \pm 14.5 \%, 25-35$ min post-tetanus; $n=6$, Figure $4 d$ ). In wild-type slices, application of sulpiride had little or no effect on the amplitude of synaptic responses either before or after tetanic stimulation (normalized amplitude $=112.1 \pm 16.9 \%, 25-35 \mathrm{~min}$ post-tetanus, $n=8$; Figure $4 \mathrm{c}$ ). These data support the possibility that Ntsr1 signaling suppresses BLA-LTP by blocking $\mathrm{D}_{2}$-like receptors. Bath application of the $\mathrm{D}_{2}$-like receptor agonist, quinpirole $(10 \mu \mathrm{M})$, induced BLA-LTP in slices from wildtype mice $(155.3 \pm 9.7 \%, 25-35 \mathrm{~min}$ post-tetanus, $n=7$; Figure $4 \mathrm{~b}$ and $\mathrm{c}$ ). This effect was not due to potentiation of basal synaptic currents because pre-tetanus synaptic currents were unaffected by quinpirole application (Figure $4 \mathrm{~b}$ ). If the activation of $\mathrm{D}_{2}$-like receptors facilitates BLA-LTP via a pathway distinct from that altered in Ntsr1KO mice, quinpirole should additively enhance BLA-LTP in Ntsr1-KO mice. However, quinpirole $(10 \mu \mathrm{M})$ did not enhance BLA-LTP in Ntsr1-KO mice (normalized 


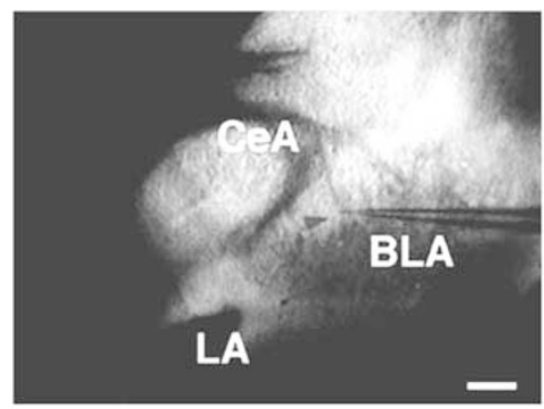

b wild-type

Ntsr1-KO
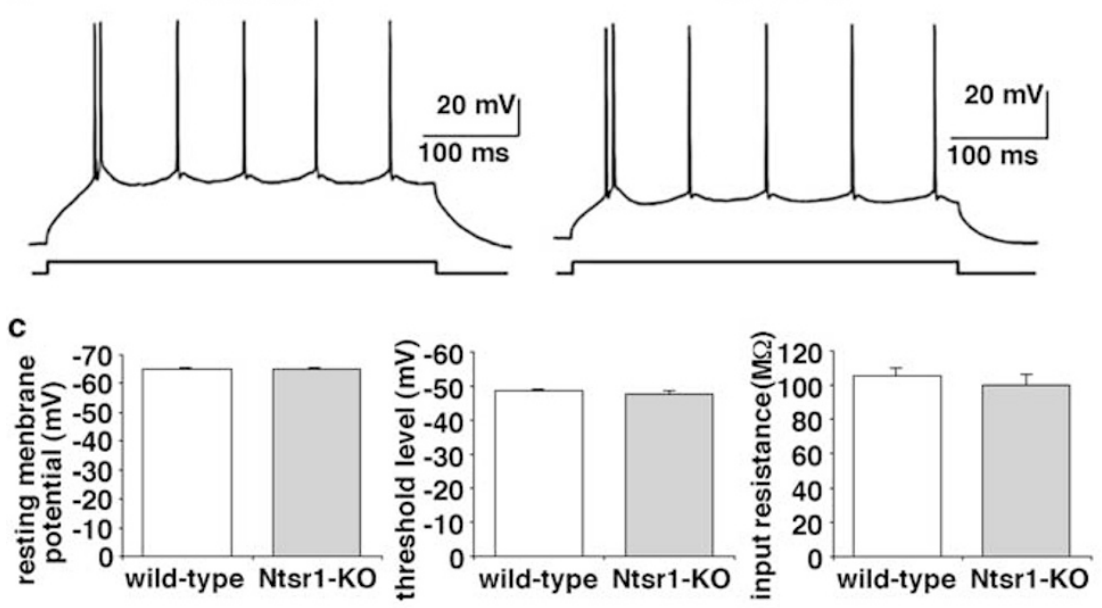

d
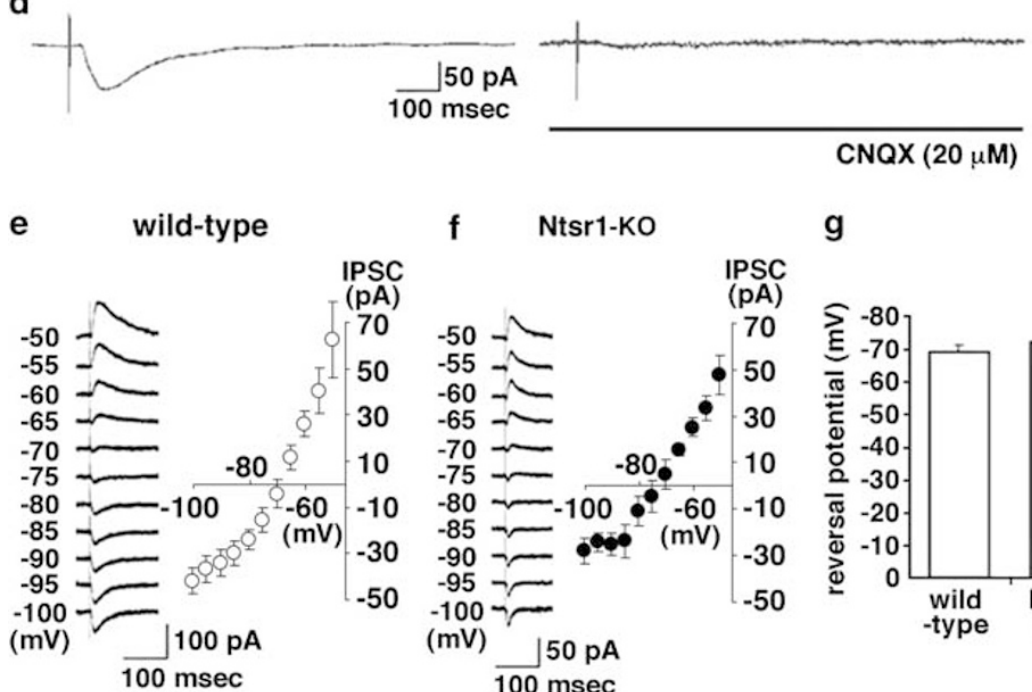

f Ntsr1-KO

g
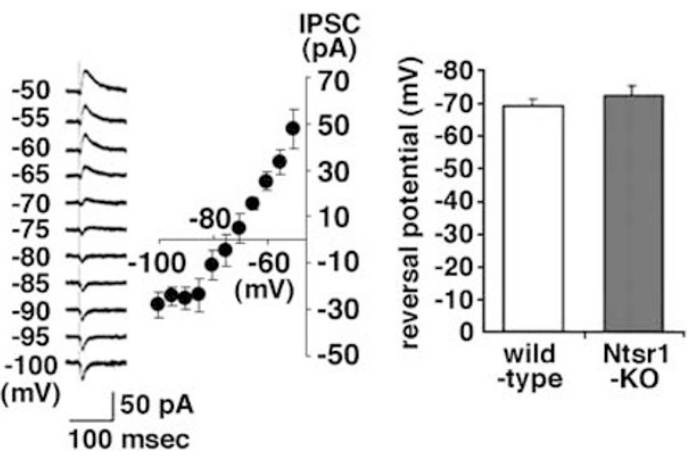

Figure I (a) A photograph showing the placement of stimulating and recording electrodes. BLA: the basolateral nucleus of the amygdala; LA: the lateral nucleus of the amygdala; CeA: the central nucleus of the amygdala. Scale bar=approximately $200 \mu \mathrm{m}$. (b) Action potentials evoked by a suprathreshold current step in wild-type and Ntsrl-KO BLA pyramidal neurons. (c) BLA pyramidal neurons were used to measure average resting membrane potential ( $n=88$ and $8 \mathrm{I}$ for wild-type and Ntsr I-KO mice, respectively), action potential threshold ( $n=88$ and $8 \mathrm{I}$ for wild-type and Ntsr I-KO mice, respectively), and input resistance ( $n=64$ and $4 \mathrm{I}$ for wild-type and NtsrI-KO mice, respectively). These data do not include the results with Cs internal solution (solution C). In this and subsequent figures, data are expressed as mean \pm standard error of mean. (d) LA stimulation-evoked synaptic currents recorded in a BLA pyramidal neuron were blocked by CNQX. (e, f) Reversal potential of $\mathrm{GABA}_{A}$ receptor-mediated inhibitory postsynaptic current (IPSC). GABA $A$ receptormediated synaptic currents in wild-type (e) and Ntsrl-KO (f) mice were measured by applying antagonists of receptors for AMPA (CNQX, $20 \mu M$ ), NMDA (MK-80I, $20 \mu \mathrm{M})$, and GABA $(C G P 4638 \mathrm{I}, 20 \mu \mathrm{M})$. Current traces at each holding potential ( -50 to $-100 \mathrm{mV}$ ) are shown in the left panel, and current amplitude is plotted against membrane potential in the right panel. The synaptic responses in (e, f) were completely blocked by application of picrotoxin $(\mathrm{I} 00 \mu \mathrm{M})$, a GABA $\mathrm{A}$ receptor antagonist, at the end of the recording. $(\mathrm{g})$ Comparison of reversal potentials in wild-type $(n=6)$ and Ntsrl-KO $(n=8)$ slices.

amplitude $=160.3 \pm 15.2 \%, 25-35$ min post-tetanus, $n=8$; Figure $4 \mathrm{~d})$, suggesting that the activation of $\mathrm{D}_{2}$-like receptors facilitates BLA-LTP in wild-type mice via the pathway altered in Ntsr1-KO mice. In other words, these data suggest that the absence of Ntsr1 facilitates BLA-LTP by enhancing $\mathrm{D}_{2}$-like receptor signaling. 

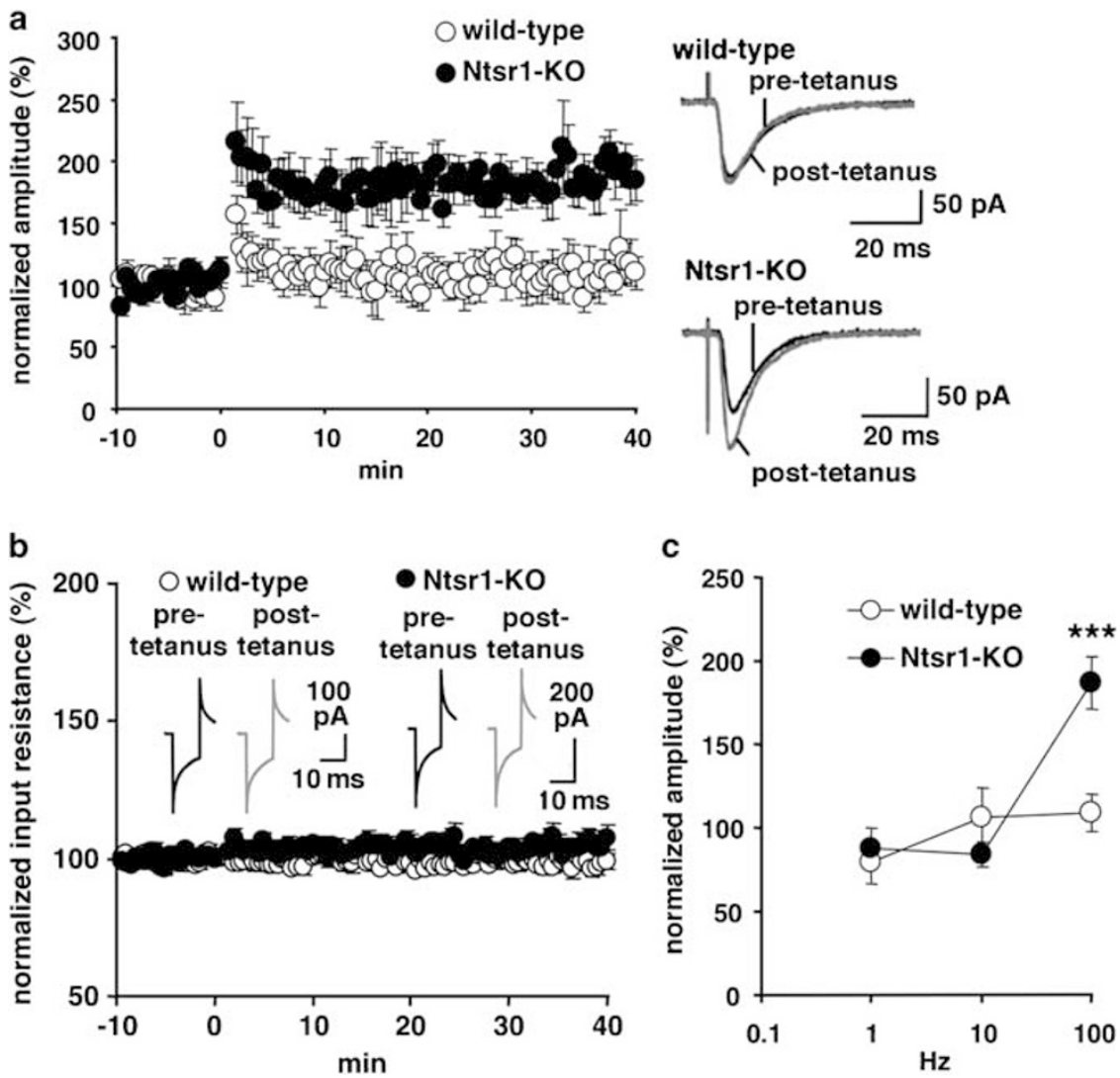

Figure 2 Tetanic stimulation induces pronounced BLA-LTP in Ntsrl-KO mice. (a) Time course of LTP in BLA pyramidal neurons from wild-type ( $n=9$ ) and $\mathrm{Ntsr}$ I-KO $(n=8)$ brain slices. The averages of 10 traces recorded 5 min just before the tetanus (pre-tetanus) and 10 traces recorded $25-30$ min after the tetanus (post-tetanus) are shown on the right. (b) Input resistance in wild-type $(n=9)$ and Ntsrl-KO $(n=8)$ BLA pyramidal neurons was unaffected by tetanic stimulation. The averages of 10 traces evoked by voltage change $(10 \mathrm{mV}, 20 \mathrm{~ms})$ recorded $5 \mathrm{~min}$ just before the tetanus (pre-tetanus) and 10 traces recorded 25-30 min after the tetanus (post-tetanus) are shown. (c) Mean values of the normalized amplitude of synaptic responses recorded 25-35 min post-tetanus in wild-type $(n=9)$ and Ntsrl-KO $(n=8)$ slices. The normalized amplitude for each experiment was calculated by averaging 20 traces. **** $P=0.0004$ vs wild-type.

We examined the effects of a $\mathrm{D}_{1}$-like receptor agonist and antagonist on BLA-LTP in slices from wild-type mice. Neither $D_{1}$-like receptor agonist SKF81297 $(10 \mu \mathrm{M}$, normalized amplitude $=107.1 \pm 8.9 \%, 25-35 \mathrm{~min}$ post-tetanus, $n=5)$ nor $\mathrm{D}_{1}$-like receptor antagonist SCH23390 $(10 \mu \mathrm{M}$, normalized amplitude $=101.6 \pm 5.5 \%, 25-35$ min post-tetanus, $n=5)$ enhanced BLA-LTP in slices from wild-type mice (Figure 4c).

\section{Evoked IPSC in BLA Pyramidal Neurons}

A previous study indicated that DA hyperpolarizes GABAergic interneurons, which reduces GABAergic inhibition for LA pyramidal neurons to facilitate LTP in pyramidal neurons (Bissiere et al, 2003). To address whether Ntsr1 regulates BLA-LTP via the modulation of GABAergic interneurons, one common method is to apply a $\mathrm{GABA}_{\mathrm{A}}$ receptor antagonist during LTP induction. However, in the case of BLA, application of the $\mathrm{GABA}_{\mathrm{A}}$ receptor antagonist picrotoxin $(100 \mu \mathrm{M})$ and consecutive stimulations of LA (over $10 \mathrm{~min}$ ) elicited epileptiform activity (Figure 5a, trace 3$)$ both in wild-type $(n=3)$ and Ntsr1-KO slices $(n=4)$. This activity continued to generate in response to subsequent stimulations once it was elicited. Until the appearance of this activity, picrotoxin elicited little effect upon synaptic response (Figure 5a, the trace 2). As reported previously (Shaban et al, 2006), epileptiform activity was not observed in the LA in our experimental conditions (data not shown). Therefore, we could not record BLA-LTP in the presence of $\mathrm{GABA}_{\mathrm{A}}$ receptor antagonist. Instead, we analyzed the input-output relation of evoked GABAergic synaptic currents in BLA pyramidal neurons with internal solution B (see Materials and methods) by stimulating inside the BLA. If GABAergic synaptic responses are modulated in the absence of Ntsr1, then the input-output relation may be changed in Ntsr1-KO mice. However, the relation between stimulus intensity and the amplitude (Figure 5b) of isolated $\mathrm{GABA}_{\mathrm{A}}$ receptor-mediated synaptic currents was essentially identical in wild-type and Ntsr1-KO mice. Moreover, the decay of GABAergic synaptic currents was not significantly different (tau value: for $0.18 \mathrm{~mA}$ stimulations, $42.56 \pm 4.94 \mathrm{~ms}$ in wild-type and $32.04 \pm 3.69 \mathrm{~ms}$ in Ntsr1-KO slices, $P=0.3216$; for $0.3 \mathrm{~mA}$ stimulations, $56.48 \pm 7.77 \mathrm{~ms}$ in wild-type $(n=5)$ and $44.59 \pm 3.35 \mathrm{~ms}$ in Ntsr1-KO slices, $n=7, P=0.1482$ ). These results suggest that the GABAergic system inside the BLA is not profoundly reduced in Ntsr1-KO mice, although it does not completely rule out the participation of the GABA system in the pronounced BLA-LTP in Ntsr1-KO mice. 

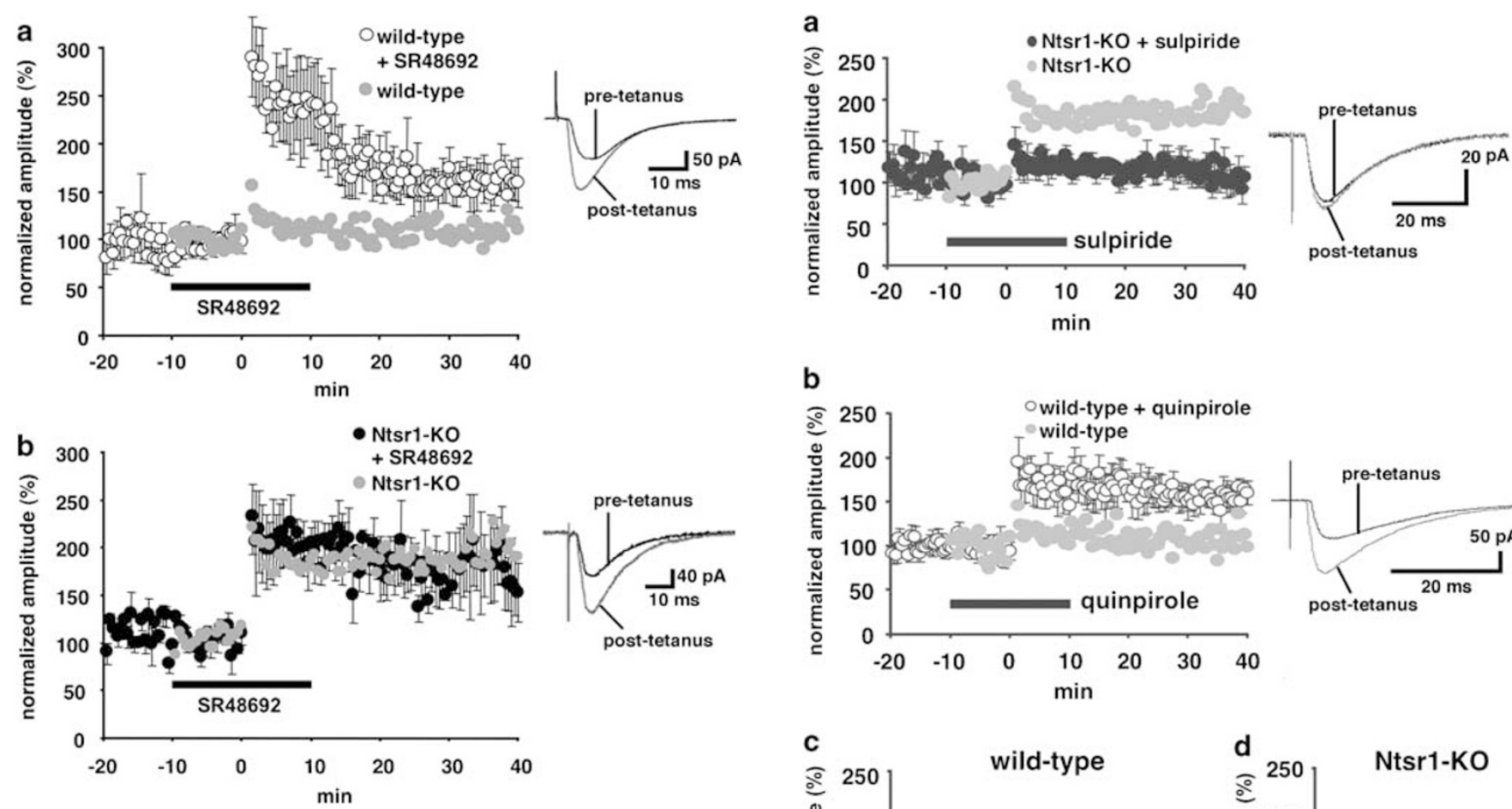

Figure 3 Effect of the Ntsrl inhibitor SR48692 on LTP in wild-type (a) and Ntsrl-KO brain slices (b). Time course of LTP in the presence of SR48692 ( $10 \mu M, n=6$ and 4 for wild-type and Ntsrl-KO, respectively). Data without SR48692 were reproduced from Figure 2a for comparison (shaded circles without error bars). SR48692 was perfused during the period indicated by the bar. The averages of 10 traces recorded 5 min prior to the tetanus (pre-tetanus) and 25-30 min after the tetanus (post-tetanus) are shown on the right.

\section{BLA-LTP in Ntsr1-KO Mice is Dependent on NMDA Receptors}

To examine whether BLA-LTP is dependent on NMDA receptor activation, we determined whether BLA-LTP is sensitive to D-APV, an NMDA receptor antagonist. Application of D-APV $(50 \mu \mathrm{M})$ reduced BLA-LTP in Ntsr1-KO slices to wild-type levels (Figure 6a; $111.8 \pm 5.7 \%, 25-35 \mathrm{~min}$ posttetanus, $n=7$ ). Application of D-APV in wild-type slices did not affect synaptic responses either before or after tetanic stimulation (Figure 6b; $109.8 \pm 13.1 \%, 25-35 \mathrm{~min}$ posttetanus, $n=4)$. Next, we compared the NMDA/non-NMDA ratio to examine the mechanism underlying the increased NMDA receptor contribution to the facilitated BLA-LTP in Ntsr1-KO slices. We recorded currents at $-80 \mathrm{mV}$ and $+40 \mathrm{mV}$ with internal solution C (see Materials and methods) in the presence of picrotoxin $(100 \mu \mathrm{M})$. Since application of picrotoxin and consecutive stimulations of LA (over $10 \mathrm{~min}$ ) elicited epileptiform activity as we showed in Figure 5a, the stimulation was discontinued during $5 \mathrm{~min}$ from the start of picrotoxin application. This treatment delayed the generation of epileptiform activity. We had recorded synaptic currents before the epileptiform activity was elicited. The non-NMDA receptor component was obtained by measuring the peak amplitude of synaptic currents recorded at $-80 \mathrm{mV}$. Because synaptic currents at $-80 \mathrm{mV}$ were diminished $80 \mathrm{~ms}$ after stimulation in all recordings (Figure $7 \mathrm{a}$, black line), we measured the amplitude of synaptic current $80 \mathrm{~ms}$ after
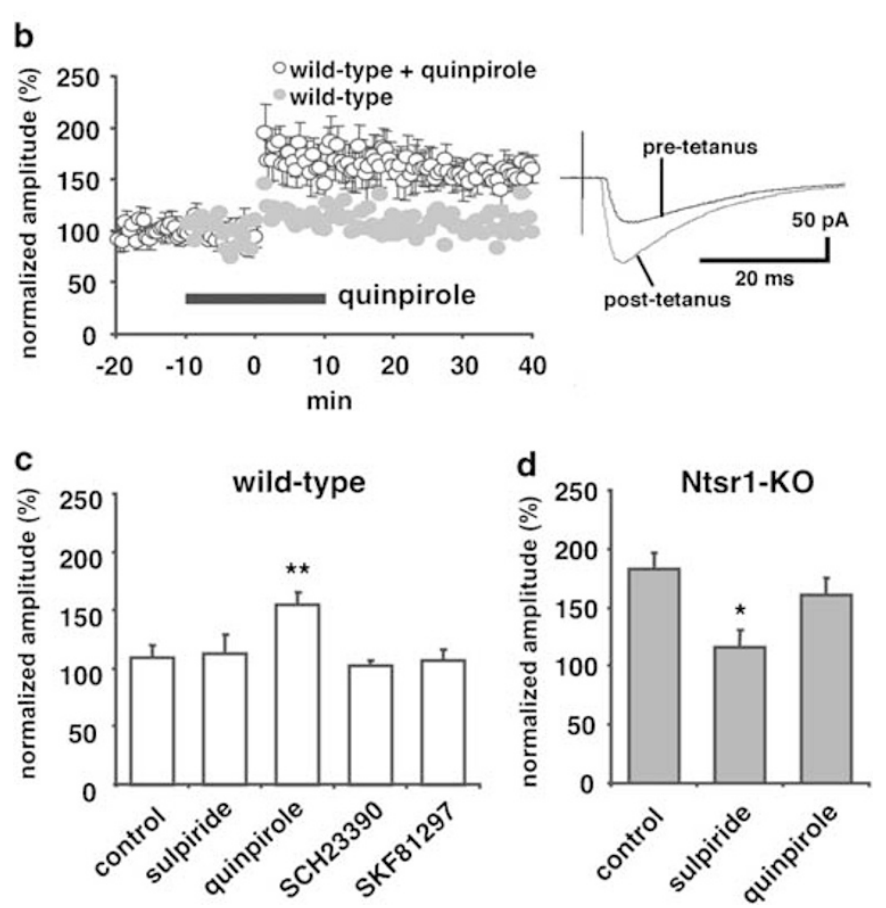

Figure 4 Effects of the $D_{1}$ - and $D_{2}$-like receptor agonist and antagonist on BLA-LTP. (a) The time course of LTP in Ntsrl-KO brain slices in the presence of sulpiride $(20 \mu \mathrm{M}, n=6)$. Data in the absence of sulpiride were reproduced from Figure 2a for comparison. Sulpiride was perfused during the period indicated by the bar. The averages of 10 traces recorded 5 min prior to the tetanus (pre-tetanus) and 25-30 min after the tetanus (posttetanus) are shown on the right. (b) Time course of LTP in wild-type slices in the presence of quinpirole $(10 \mu \mathrm{M}, n=6)$. Data without quinpirole were reproduced from Figure 3 a for comparison. Quinpirole was perfused during the period indicated by the bar. The averages of 10 traces recorded $5 \mathrm{~min}$ prior to tetanic stimulation (pre-tetanus) and 25-30 min after tetanic stimulation (post-tetanus) are shown on the right. Mean values of normalized synaptic responses recorded in wild-type (c) or Ntsrl-KO slices (d) at 25-35 min after tetanus in the presence of reagents indicated below the graphs. The normalized amplitude for each experiment was calculated using 20 traces recorded $25-35$ min post-tetanus, and values from 5 to 8 mice were averaged. Control values (in ACSF) were reproduced from Figure $3 \mathrm{~b}$ for comparison. Results of the Fisher's PLSD test: wild-type mice, ${ }^{*} * P=0.0079$ for control vs quinpirole; Ntsr I-KO mice, $* P=0.0410$ for control vs sulpiride.

stimulation at $+40 \mathrm{mV}$ as NMDA receptor currents (Figure 7a, arrow). We calculated the NMDA/non-NMDA ratio by dividing the component of NMDA receptor current $(+40 \mathrm{mV})$ by the component of non-NMDA receptor current $(-80 \mathrm{mV})$. As shown in Figure 7, the NMDA/non-NMDA ratio of Ntsr1-KO mice was significantly greater than that of wild-type mice (Figure 7b; Ntsr1-KO, $0.344 \pm 0.048, n=19$; wild-type, $0.163 \pm 0.024, n=13$ ). We confirmed the effect of 


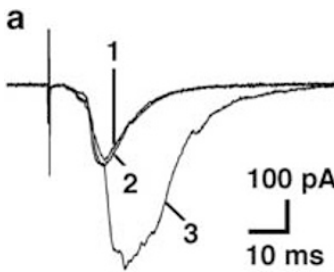

b

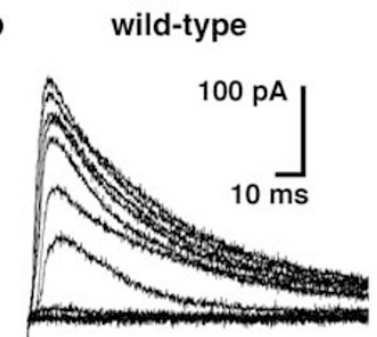

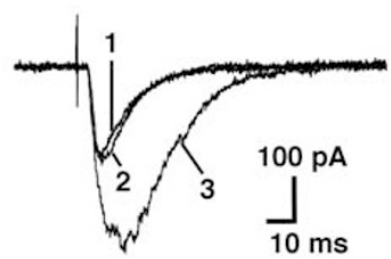

Ntsr1-KO

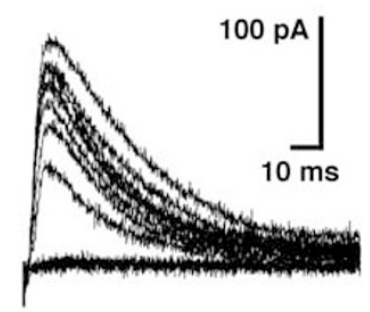

Figure 5 (a) Effects of picrotoxin on LA stimulation-evoked synaptic currents in BLA neurons. Trace I was recorded before picrotoxin application, and traces 2 and 3 were recorded at 5 th and 10 th min from the start of picrotoxin application $(100 \mu \mathrm{M})$, respectively. Note epileptiform activity in trace 3. (b) (top) Traces of isolated GABA $A_{A}$ receptor IPSCs evoked by $0.1-0.3 \mathrm{~mA}$ stimulations; (bottom) the relationship of stimulus intensity and amplitude of the isolated $G A B A_{A}$ receptor IPSCs between wild-type and Ntsrl-KO mice.

D-APV on the outward current mediated by NMDA receptors (Figure 7a).

To address the effect of quinpirole on the NMDA receptor-mediated synaptic currents, we measured the NMDA receptor-mediated currents in Mg-free ACSF containing CNQX and CGP46381 with inter-pipette solution A (see Materials and methods) at $-70 \mathrm{mV}$ (to minimize the contribution of $\mathrm{GABA}_{\mathrm{A}}$ receptor-mediated currents, see Figure 1e-g). The NMDA receptor-mediated currents were increased by the application of quinpirole $(10 \mu \mathrm{M})$ in the slices from wild-type mice, but not in the slices from Ntsr1$\mathrm{KO}$ mice (Figure 7c). The mean normalized amplitude (to control) of 10 records from 5 to $10 \mathrm{~min}$ after the start of quinpirole application were $160.8 \pm 10.9 \% \quad(n=6)$ and $117.3 \pm 9.4 \%(n=5)$ for wild-type and Ntsr1-KO mice, respectively. These values were significantly different. After recording, the synaptic currents were confirmed to be abolished by D-APV ( $50 \mu \mathrm{M}$, data not shown). In response to washout of quinpirole, we could not observe the complete
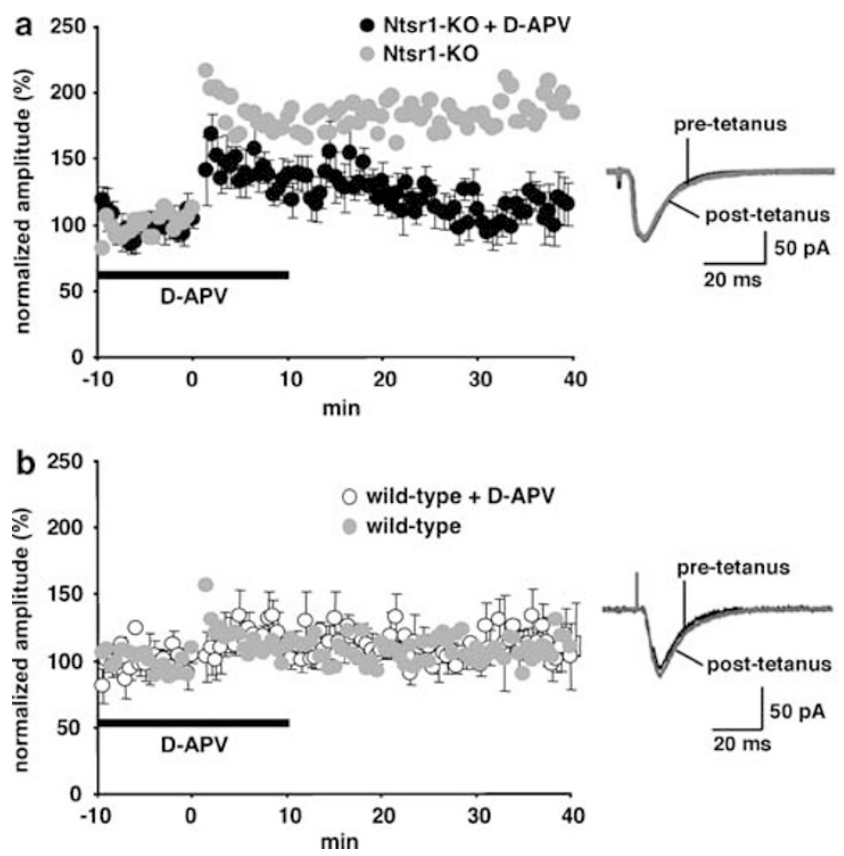

Figure 6 The NMDA receptor antagonist, D-APV, abolishes BLA-LTP in brain slices from Ntsr I-KO mice. (a) Time course of LTP in Ntsr I-KO slices in the presence of D-APV $(50 \mu \mathrm{M}, n=7)$. Data without D-APV were reproduced from Figure $2 \mathrm{a}$ for comparison. The averages of 10 traces recorded $5 \mathrm{~min}$ prior to tetanic stimulation (pre-tetanus) and 25-30 min after tetanic stimulation (post-tetanus) are shown on the right. (b) The analogous experiment performed in wild-type slices $(n=4)$.

recovery of augmented NMDA receptor currents to the baseline level. These results suggest that the activation of $\mathrm{D}_{2}$-like receptors facilitates NMDA receptor-induced synaptic currents in wild-type mice.

\section{DISCUSSION}

The main finding of our present study is that a lack of Ntsr1 permits a pronounced tetanus-induced LTP in LA-BLA synapses. In these synapses, the LTP could not be observed in our wild-type mice. Notably, robust LTP was elicited not only by conventional gene knockout of Nstr1 but also by acute pharmacological blockade of Ntsr1. Our analysis suggests that the lack of Ntsrl increases the activity of NMDA receptors in LA-BLA synapses by enhancing $\mathrm{DA} \mathrm{D}_{2}$-like receptor activity.

\section{LTP in the LA-BLA Synapses}

There are two reports from the same group that tetanus stimulation of the LA in the mouse brain slices elicits modest LTP (1.2- to 1.4-fold increase to pre-tetanus) in the BLA (DeBock et al, 2003; Rammes et al, 2000). In our present study, however, we did not observe consistent BLALTP in wild-type mice. There may be several reasons for this discrepancy: (1) differences in the recording methods (field recordings in the previous reports $v s$ patch clamp recordings in our case); (2) differences in mouse strain (F1 hybrids of a cross $\mathrm{FVB} / \mathrm{N} \times \mathrm{C} 57 \mathrm{BL} / 6 \mathrm{~J}$ or $\mathrm{FVB} / \mathrm{N}$ in the previous 

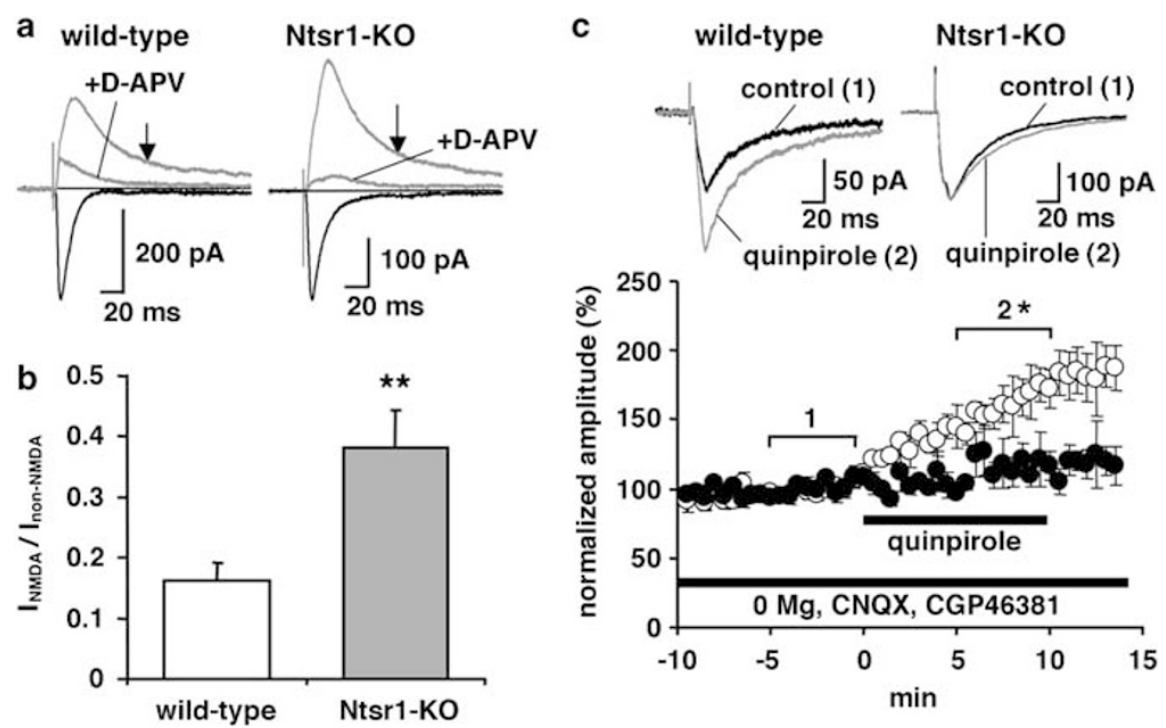

Figure 7 The NMDA/non-NMDA ratio for the LA-BLA pathway is increased in Ntsrl-KO slices. (a) Traces showing synaptic currents recorded at $-80 \mathrm{mV}$ and at $+40 \mathrm{mV}$ in the slices from wild-type mice and Ntsrl-KO mice. The AMPA receptor component was obtained by measuring the peak amplitude of synaptic currents recorded at $-80 \mathrm{mV}$. The NMDA receptor component was obtained by measuring the current amplitude at $80 \mathrm{~ms}$ after the stimulation was recorded at $+40 \mathrm{mV}$ (arrow). (b) The average NMDA/non-NMDA ratio for wild-type $(n=13)$ and Ntsrl-KO mice $(n=19)$. ** $P=0.0066$ vs wild type. (c) (top) Traces of pharmacologically isolated NMDA receptor-mediated synaptic currents. Ten traces just prior to the application of quinpirole $(10 \mu \mathrm{M})$ were averaged (trace labeled control), and ten traces from 5 to $10 \mathrm{~min}$ after the start of the application of quinpirole were averaged (trace labeled 'quinpirole'). (bottom) Time course of the effect of quinpirole on the amplitude of NMDA receptor-mediated synaptic currents in the BLA pyramidal neurons of wild-type mice $(n=6)$ and Ntsrl-KO mice $(n=5)$. $* P=0.0165$ vs wild type.

reports $v s$ mouse backcrossed $25-30$ times to $\mathrm{C} 57 \mathrm{BL} / 6 \mathrm{~J}$ in our case); and (3) differences in mouse age (9-12 months old or 6-8 weeks old in the previous reports $v s$ 4-5 weeks old in our case). In particular, the differences in the strain used are important because the FVB/NJ strain exhibits unusually low performance in contextual learning in fear conditioning (Owen et al, 1997).

Two studies have reported that $1-\mathrm{Hz}$ stimulation $(900$ stimulations total) evokes NMDA receptor-dependent long-term depression (LTD) in the BLA (Rammes et al, 2000; Wang and Gean, 1999). However, under our experimental conditions $1-\mathrm{Hz}$ stimulation (500 stimulations total) did not induce statistically significant LTD in either wildtype or Ntsr1-KO brain slices, although there was an apparent tendency in this regard. One potential explanation for these differences may be the difference of total stimulations (900 pulses in the previous studies vs 500 pulses in our case).

Under our recording conditions, the internal solution contained $30 \mathrm{mM} \mathrm{KCl}$ (internal solution A). Accordingly, the reversal potential of the $\mathrm{GABA}_{\mathrm{A}}$ receptor-mediated currents theoretically should be more positive than $-40 \mathrm{mV}$; however, the measured reversal potential elicited by stimulation of the LA under blockade of AMPA and NMDA receptors was about $-70 \mathrm{mV}$ (Figure 1g). We conjecture that the discrepancy between the theoretical and measured $\mathrm{Cl}^{-}$equilibrium potentials reflects the possibility that the GABAergic synapse activated by LA stimulation was on the distal dendrite of the BLA neurons that were recorded. We suspect that the internal solution was not adequately perfused at the distal site of the thin dendrite, and insufficient exchange of intracellular solution perturbs the shift of the equilibrium potential, leaving it near the original value. This speculation is supported by reports on the presence of GABAergic synapses in distal dendrites in BLA pyramidal neurons (Muller et al, 2006, 2007).

Our data suggest that changes in synaptic plasticity induced by a lack of Ntsr1 occur only when high-frequency stimulation such as $100 \mathrm{~Hz}$ is applied to the LA. Firing rates of individual LA pyramidal neurons are notoriously low (Pare and Gaudreau, 1996). Accordingly, it seems that the effectiveness of Ntsr1 in synaptic plasticity in BLA pyramidal neurons is limited when an individual LA neuron fires with extraordinarily high frequency or multiple LA neurons projecting to one BLA neuron fire with relatively high frequency in a non-synchronous manner.

\section{Ntsr $1 / \mathrm{D}_{2}$-Like Receptor-NMDA Receptor Interaction in the BLA}

Figure 8 illustrates the hypothesis of the mechanism of enhanced LTP in the BLA. Mechanism 1 (labeled M1) is based on the hypothesis that Ntsr1, $\mathrm{D}_{2}$-like receptors, and the NMDA receptors are present in the same BLA pyramidal neuron. In the neuron, activation of $\mathrm{D}_{2}$-like receptors by $\mathrm{DA}$ from a DA/NTergic fiber originating in the ventral tegmental area augments the activity of NMDA receptors, thereby enhancing NMDA receptor-dependent LTP in LABLA synapses. However, NT simultaneously released from the DA/NT fiber suppresses the activity of $\mathrm{D}_{2}$-like receptors via Ntsr1. This suppression attenuates activation of NMDA receptors by $\mathrm{D}_{2}$-like receptor activation; hence, LTP in LABLA synapses is not evident in wild-type mice. In Ntsr1-KO mice, this suppression by $\mathrm{Ntsr} 1$ to $\mathrm{D}_{2}$-like receptors is lacking, and thus NMDA receptors are activated by $\mathrm{D}_{2}$-like 


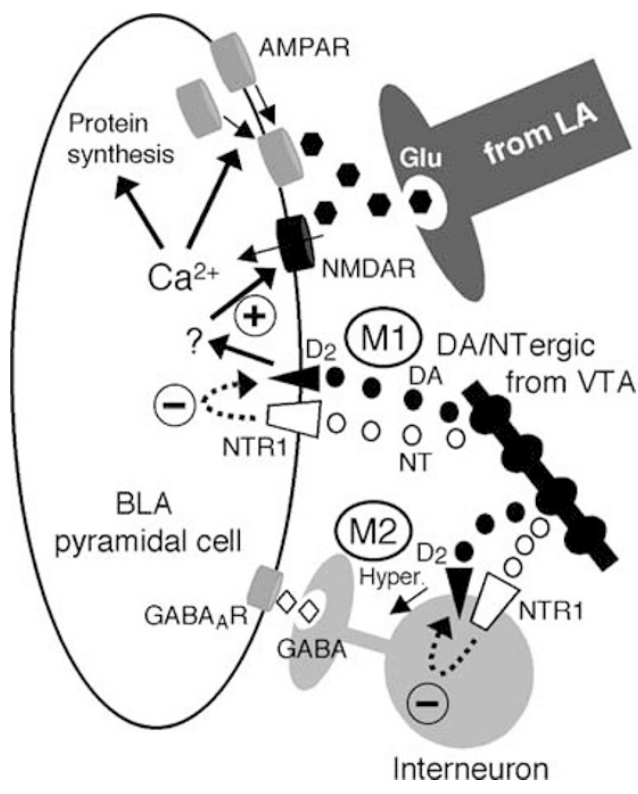

Figure 8 Possible mechanisms by which Ntsrl regulates BLA-LTP. Mechanism I (MI) is based on the hypothesis that Ntsr I, $D_{2}$-like receptors, and NMDA receptors are present in the same BLA pyramidal neuron. In the pyramidal neuron, activation of $D_{2}$-like receptors by DA from a DA NTregic fiber originating in the ventral tegmental area (VTA) augments the activity of NMDA receptors (+), thereby enhancing NMDA receptordependent LTP in LA-BLA synapses. In wild-type mice, NT released simultaneously with DA from the DA/NT fiber suppresses (-) the activity of $\mathrm{D}_{2}$-like receptors via $\mathrm{Ntsrl}$. The suppressive action of $\mathrm{Ntsrl}$ attenuates NMDA receptor activation by $D_{2}$-like receptors, consequently interfering with LTP in LA-BLA synapses. In Ntsrl-KO mice, this suppression of $\mathrm{D}_{2}$-like receptors is lacking, and thus NMDA receptors are activated upon $\mathrm{D}_{2}$-like receptor activation, which thereby induces pronounced BLA-LTP. Another hypothesis, illustrated by mechanism 2 (M2), is that Ntsr I-D2-like receptor interaction occurs in GABAergic interneurons. The attenuation of the GABAergic inhibitory system may facilitate LTP. See Discussion for details.

receptor activation, which induces a pronounced BLA-LTP. Because the NMDA/non-NMDA receptor-mediated current ratio was increased in Ntsr1-KO mice even under the baseline condition (without tetanus stimulation; Figure 7), spontaneously released DA (or the steady-state DA concentration) is enough to activate this mechanism in Ntsr1KO mice. Our observation that NMDA receptor-induced synaptic currents are potentiated by quinpirole in wild-type mice (Figure 7) also supports this mechanism 1. The absence of the potentiating action of quinpirole in Ntsr1-KO mice suggests that NMDA receptor is already potentiated because of a lack of Ntsr1. As shown in Figure 7, the effects of quinpirole were persistent and not recoverable. The persistent action of quinpirole on NMDA receptor-mediated currents is in agreement with the action of quinpirole in the hippocampus and prefrontal cortex (Beazely et al, 2006; Kotecha et al, 2002).

Because NT-induced DA release is dramatically reduced in Ntsr1-KO mice (Leonetti et al, 2004), it is unlikely that DA release from DA/NTergic fibers is increased in Ntsr1KO mice. Rather, we speculate that the mechanism 1 is based on the absence of inhibitory constraint by Ntsr1 on $\mathrm{D}_{2}$-like receptors. The mechanism by which $\mathrm{D}_{2}$-like receptor activation increases NMDA receptor activity is obscure.
There are several possibilities in this regard, including facilitation of targeting of NMDA receptors to LA-BLA synapses or modification of previously targeted NMDA receptors by phosphorylation or by depolarization of local membrane potentials. Notably, several studies have indicated that pyramidal neurons are excited via activation of $\mathrm{D}_{2}$-like receptors (Haj-Dahmane, 2001; Kroner et al, 2005; Yang et al, 1991). Consistent with these reports, we observed that quinpirole elicited small $(\sim 3 \mathrm{mV})$ depolarization of BLA pyramidal neurons (data not shown).

The second mechanism (M2 in Figure 8) is based on the possibility that a lack of Ntsr1 suppresses GABAergic interneurons via activation of $\mathrm{D}_{2}$-like receptors. NT activates GABAergic neurons via Ntsr1 in the prefrontal cortex and globus pallidus (Ferraro et al, 1997; Petrie et al, 2005), and the suppression of the GABAergic inhibitory system is broadly recognized as the factor that facilitates LTP (Bissiere et al, 2003; Rodriguez Manzanares et al, 2005). In this case, the activation of $\mathrm{D}_{2}$-like receptors would somatodendritically hyperpolarize interneurons or reduce GABA release by acting on GABAergic presynaptic terminals. In the present study, generation of robust epileptiform activity in the presence of a $G_{A B A}$ receptor antagonist interfered with direct verification of this possibility in the BLA (Figure 5a). Our observation that the input-output relation of evoked GABAergic IPSC was unchanged in Ntsr1-KO mice compared with wild-type mice thus runs counter to this mechanism (Figure 5b). Yet it remains possible that interneurons are more potently inhibited by $\mathrm{D}_{2}$-like receptors during tetanus stimulation. However, because NMDA receptor activity was enhanced in pyramidal neurons of Ntsr1-KO mice (Figure 7), and because BLA-LTP depends on NMDA receptors (Figure 6), mechanism 1 contributes at least in part to the enhanced BLA-LTP in Ntsr1-KO mice. The possibility that the Ntsr1/ $\mathrm{D}_{2}$-like receptor system influences glutamate release from presynaptic sites of LA-BLA synapses (see Yin et al, 2007) is unlikely because application of quinpirole did not induce a change in the amplitude of the baseline synaptic response (Figure $4 \mathrm{~b}$ ).

In conclusion, we have demonstrated that a lack of Ntsr1 enhances LTP in LA-BLA synapses in mouse. Activation of $\mathrm{D}_{2}$-like receptors and consequent activation of NMDA receptors is one of the plausible mechanisms underlying enhanced LTP in the absence of Ntsrl. These results suggest that NT, via Ntsrl, qualifies as a potential inhibitory neurotransmitter for synaptic plasticity in mouse LA-BLA synapses.

\section{ACKNOWLEDGEMENTS}

We thank Dr Wendy C Chang (Sanofi-Synthelabo Research, Malvern, PA) for SR48692. We thank Mr Takagaki for editing this paper. This study was supported in part by Grants-in-Aid for Scientific Research from the Ministry of Health, Labour and Welfare of Japan, Grants-in-Aid for Scientific Research from the Ministry of Education, Culture, Sports, Science and Technology of Japan, the Program for Promotion of Fundamental Studies in Health Sciences of the National Institute of Biomedical Innovation, and a grant from the Japan Science and Technology Agency. 


\section{DISCLOSURE/CONFLICTS OF INTEREST}

The author(s) declare that no financial support or compensation has been received from any individual or corporate entity over the past 3 years for research or professional service, and there are no personal financial holdings that could be perceived as constituting a potential conflict of interest.

\section{REFERENCES}

Alexander MJ, Leeman SE (1998). Widespread expression in adult rat forebrain of mRNA encoding high-affinity neurotensin receptor. J Comp Neurol 402: 475-500.

Asan E (1998). The catecholaminergic innervation of the rat amygdala. Adv Anat Embryol Cell Biol 142: 1-118.

Beazely MA, Tong A, Wei WL, Van Tol H, Sidhu B, MacDonald JF (2006). D2-class dopamine receptor inhibition of NMDA currents in prefrontal cortical neurons is platelet-derived growth factor receptor-dependent. J Neurochem 98: 1657-1663.

Binder EB, Kinkead B, Owens MJ, Kilts CD, Nemeroff CB (2001a). Enhanced neurotensin neurotransmission is involved in the clinically relevant behavioral effects of antipsychotic drugs: evidence from animal models of sensorimotor gating. J Neurosci 21: 601-608.

Binder EB, Kinkead B, Owens MJ, Nemeroff CB (2001b). Neurotensin and dopamine interactions. Pharmacol Rev 53: 453-486.

Bissiere S, Humeau Y, Luthi A (2003). Dopamine gates LTP induction in lateral amygdala by suppressing feedforward inhibition. Nat Neurosci 6: 587-592.

Caceda R, Kinkead B, Owens MJ, Nemeroff CB (2005). Virally mediated increased neurotensin 1 receptor in the nucleus accumbens decreases behavioral effects of mesolimbic system activation. J Neurosci 25: 11748-11756.

Chalon P, Vita N, Kaghad M, Guillemot M, Bonnin J, Delpech B et al (1996). Molecular cloning of a levocabastine-sensitive neurotensin binding site. FEBS Lett 386: 91-94.

Davis M (1997). Neurobiology of fear responses: the role of the amygdala. J Neuropsychiatry Clin Neurosci 9: 382-402.

DeBock F, Kurz J, Azad SC, Parsons CG, Hapfelmeier G, Zieglgansberger W et al (2003). Alpha2-adrenoreceptor activation inhibits LTP and LTD in the basolateral amygdala: involvement of $\mathrm{Gi} /$ o-protein-mediated modulation of $\mathrm{Ca}^{2+}$ channels and inwardly rectifying $\mathrm{K}^{+}$-channels in LTD. Eur $J$ Neurosci 17: 1411-1424.

Diaz-Cabiale Z, Fuxe K, Narvaez JA, Finetti S, Antonelli T, Tanganelli $S$ et al (2002). Neurotensin-induced modulation of dopamine D2 receptors and their function in rat striatum: counteraction by a NTR1-like receptor antagonist. Neuroreport 13: 763-766.

Feifel D, Reza TL, Wustrow DJ, Davis MD (1999). Novel antipsychotic-like effects on prepulse inhibition of startle produced by a neurotensin agonist. J Pharmacol Exp Ther 288: 710-713.

Fendt M, Fanselow MS (1999). The neuroanatomical and neurochemical basis of conditioned fear. Neurosci Biobehav Rev 23: 743-760.

Ferraro L, O’Connor WT, Antonelli T, Fuxe K, Tanganelli S (1997). Differential effects of intrastriatal neurotensin(1-13) and neurotensin(8-13) on striatal dopamine and pallidal GABA release. A dual-probe microdialysis study in the awake rat. Eur $J$ Neurosci 9: 1838-1846.

Greba Q, Gifkins A, Kokkinidis L (2001). Inhibition of amygdaloid dopamine D2 receptors impairs emotional learning measured with fear-potentiated startle. Brain Res 899: 218-226.

Greba Q, Kokkinidis L (2000). Peripheral and intraamygdalar administration of the dopamine D1 receptor antagonist $\mathrm{SCH}$
23390 blocks fear-potentiated startle but not shock reactivity or the shock sensitization of acoustic startle. Behav Neurosci 114: 262-272.

Guarraci FA, Frohardt RJ, Falls WA, Kapp BS (2000). The effects of intra-amygdaloid infusions of a D2 dopamine receptor antagonist on Pavlovian fear conditioning. Behav Neurosci 114: 647-651.

Guarraci FA, Frohardt RJ, Kapp BS (1999). Amygdaloid D1 dopamine receptor involvement in Pavlovian fear conditioning. Brain Res 827: 28-40.

Gully D, Canton M, Boigegrain R, Jeanjean F, Molimard JC, Poncelet $M$ et al (1993). Biochemical and pharmacological profile of a potent and selective nonpeptide antagonist of the neurotensin receptor. Proc Natl Acad Sci USA 90: 65-69.

Haj-Dahmane S (2001). D2-like dopamine receptor activation excites rat dorsal raphe 5-HT neurons in vitro. Eur J Neurosci 14: 125-134.

Kotecha SA, Oak JN, Jackson MF, Perez Y, Orser BA, Van Tol HH et al (2002). A D2 class dopamine receptor transactivates a receptor tyrosine kinase to inhibit NMDA receptor transmission. Neuron 35: 1111-1122.

Kroner S, Rosenkranz JA, Grace AA, Barrionuevo G (2005). Dopamine modulates excitability of basolateral amygdala neurons in vitro. J Neurophysiol 93: 1598-1610.

LeDoux JE (2000). Emotion circuits in the brain. Annu Rev Neurosci 23: 155-184.

Leonetti M, Brun P, Clerget M, Steinberg R, Soubrie P, Renaud B et al (2004). Specific involvement of neurotensin type 1 receptor in the neurotensin-mediated in vivo dopamine efflux using knock-out mice. J Neurochem 89: 1-6.

Maeno H, Yamada K, Santo-Yamada Y, Aoki K, Sun YJ, Sato E et al (2004). Comparison of mice deficient in the high- or low-affinity neurotensin receptors, Ntsr1 or Ntsr2, reveals a novel function for Ntsr2 in thermal nociception. Brain Res 998: 122-129.

Maren S (1999). Long-term potentiation in the amygdala: a mechanism for emotional learning and memory. Trends Neurosci 22: 561-567.

Marowsky A, Yanagawa Y, Obata K, Vogt KE (2005). A specialized subclass of interneurons mediates dopaminergic facilitation of amygdala function. Neuron 48: 1025-1037.

Mazella J, Botto JM, Guillemare E, Coppola T, Sarret P, Vincent JP (1996). Structure, functional expression, and cerebral localization of the levocabastine-sensitive neurotensin/neuromedin $\mathrm{N}$ receptor from mouse brain. J Neurosci 16: 5613-5620.

Mazella J, Zsurger N, Navarro V, Chabry J, Kaghad M, Caput D et al (1998). The $100-\mathrm{kDa}$ neurotensin receptor is gp95/sortilin, a non-G-protein-coupled receptor. J Biol Chem 273: 26273-26276.

Moyse E, Rostene W, Vial M, Leonard K, Mazella J, Kitabgi P et al (1987). Distribution of neurotensin binding sites in rat brain: a light microscopic radioautographic study using monoiodo $\left[{ }^{125} \mathrm{I}\right]$ Tyr3-neurotensin. Neuroscience 22: 525-536.

Muller JF, Mascagni F, McDonald AJ (2006). Pyramidal cells of the rat basolateral amygdala: synaptology and innervation by parvalbumin-immunoreactive interneurons. J Comp Neurol 494: 635-650.

Muller JF, Mascagni F, McDonald AJ (2007). Postsynaptic targets of somatostatin-containing interneurons in the rat basolateral amygdala. J Comp Neurol 500: 513-529.

Owen EH, Logue SF, Rasmussen DL, Wehner JM (1997). Assessment of learning by the Morris water task and fear conditioning in inbred mouse strains and F1 hybrids: implications of genetic background for single gene mutations and quantitative trait loci analyses. Neuroscience 80: 1087-1099.

Pare D, Gaudreau H (1996). Projection cells and interneurons of the lateral and basolateral amygdala: distinct firing patterns and differential relation to theta and delta rhythms in conscious cats. J Neurosci 16: 3334-3350. 
Petrie KA, Schmidt D, Bubser M, Fadel J, Carraway RE, Deutch AY (2005). Neurotensin activates GABAergic interneurons in the prefrontal cortex. J Neurosci 25: 1629-1636.

Pitkanen A, Savander V, LeDoux JE (1997). Organization of intraamygdaloid circuitries in the rat: an emerging framework for understanding functions of the amygdala. Trends Neurosci 20: 517-523.

Pitkanen A, Stefanacci L, Farb CR, Go GG, LeDoux JE, Amaral DG (1995). Intrinsic connections of the rat amygdaloid complex: projections originating in the lateral nucleus. J Comp Neurol 356: 288-310.

Rammes G, Steckler T, Kresse A, Schutz G, Zieglgansberger W, Lutz B (2000). Synaptic plasticity in the basolateral amygdala in transgenic mice expressing dominant-negative cAMP response element-binding protein (CREB) in forebrain. Eur J Neurosci 12: 2534-2546.

Rodriguez Manzanares PA, Isoardi NA, Carrer HF, Molina VA (2005). Previous stress facilitates fear memory, attenuates GABAergic inhibition, and increases synaptic plasticity in the rat basolateral amygdala. J Neurosci 25: 8725-8734.

Sarret P, Krzywkowski P, Segal L, Nielsen MS, Petersen CM, Mazella J et al (2003). Distribution of NTS3 receptor/sortilin mRNA and protein in the rat central nervous system. J Comp Neurol 461: 483-505.
Shaban H, Humeau Y, Herry C, Cassasus G, Shigemoto R, Ciocchi S et al (2006). Generalization of amygdala LTP and conditioned fear in the absence of presynaptic inhibition. Nat Neurosci 9: 1028-1035.

Tanaka K, Masu M, Nakanishi S (1990). Structure and functional expression of the cloned rat neurotensin receptor. Neuron 4: 847-854.

von Euler G, Fuxe K, Benfenati F, Hansson T, Agnati LF, Gustafsson JA (1989). Neurotensin modulates the binding characteristics of dopamine D2 receptors in rat striatal membranes also following treatment with toluene. Acta Physiol Scand 135: 443-448.

Wang SJ, Gean PW (1999). Long-term depression of excitatory synaptic transmission in the rat amygdala. J Neurosci 19: 1065610663.

Yang CR, Bourque CW, Renaud LP (1991). Dopamine D2 receptor activation depolarizes rat supraoptic neurones in hypothalamic explants. J Physiol 443: 405-419.

Yin HH, Adermark L, Lovinger DM (2007). Neurotensin reduces glutamatergic transmission in the dorsolateral striatum via retrograde endocannabinoid signaling. Neuropharmacology, print copy in press (originally published online 22 June 2007, at http://dx.doi.org/10.1016/j.neuropharm.2007.06.004).

Zushida K, Sakurai M, Wada K, Sekiguchi M (2007). Facilitation of extinction learning for contextual fear memory by PEPA: a potentiator of AMPA receptors. J Neurosci 27: 158-166. 